\title{
Sensitive fluorescent hybridisation protocol development for simultaneous detection of microRNA and cellular marker proteins (in the retina)
}

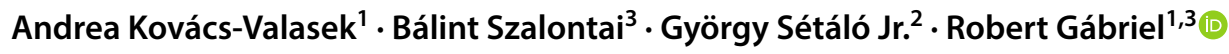

Accepted: 31 July 2018 / Published online: 7 August 2018

(c) The Author(s) 2018

\begin{abstract}
Nowadays, increasing number of microRNAs are found to have crucial roles in various physiological processes through gene expression regulation via RNA silencing as a result of base pairing with complementary mRNA sequences. To reveal the spatial distribution of microRNA expression in tissues, in situ hybridisation is the only method developed to date. This work aims to provide a novel approach to obtain information on the possible involvement of microRNA-s in regulatory processes under experimental conditions by enhancing fluorescent detection of microRNA labelling. Developing Wistar rats were used as a model system to analyse retinal microRNA expression in the first 3 postnatal weeks. Using cryosections, the crucial elements of optimal labels were (1) the concentration and duration of proteinase K treatment, (2) hybridisation temperature of microRNA probes and (3) temperature of stringency washes. Further improvements made possible to combine our in situ hybridisation protocol with double-label immunofluorescence allowing for the simultaneous detection of microRNA-s with high sensitivity and a neuronal cell marker and/or a synaptic marker protein. Thus, the regulatory microRNA-s can be localised in an identified cell type along with its potential target protein. We believe that our protocol can be easily adapted for a variety of tissues of different origins, developmental stages and experimental conditions.
\end{abstract}

Keywords MicroRNA $\cdot$ In situ hybridisation $\cdot$ Immunocytochemistry $\cdot$ Tyramide signal amplification $\cdot$ mir-9 $\cdot$ mir-23

\begin{tabular}{|c|c|c|c|c|}
\hline \multicolumn{3}{|c|}{ Abbreviations } & $\mathrm{SSC}$ & Saline-sodium citrate \\
\hline \multicolumn{2}{|c|}{ Anti-DIG HRP } & $\begin{array}{l}\text { Anti-digoxigenin } \\
\text { (mouse)-horseradish peroxidase }\end{array}$ & $\mathrm{NaH}_{2} \mathrm{PO}_{4}$ & $\begin{array}{l}\text { Sodium-dihydrogen phosphate } \\
\text { anhydrous }\end{array}$ \\
\hline \multicolumn{2}{|c|}{ DEPC } & Diethylpyrocarbonate & TEA & Triethanolamine \\
\hline \multicolumn{2}{|c|}{$\mathrm{Na}_{2} \mathrm{HPO}_{4} \times 2 \mathrm{H}_{2} \mathrm{O}$} & $\begin{array}{l}\text { Di-sodium hydrogen phosphate } \\
\text { dehydrate }\end{array}$ & TSA & Tyramide signal amplification \\
\hline \multicolumn{2}{|c|}{ EDTA } & Ethylenediaminetetraacetic acid & \multirow{3}{*}{\multicolumn{2}{|c|}{ Introduction }} \\
\hline \multicolumn{2}{|c|}{$\mathrm{HCl}$} & Hydrochloric acid & & \\
\hline \multicolumn{2}{|c|}{ ISH } & In situ hybridisation & & \\
\hline \multicolumn{2}{|c|}{ PFA } & Paraformaldehyde & \multirow{4}{*}{\multicolumn{2}{|c|}{$\begin{array}{l}\text { MicroRNA-s generate a well-controlled, fine-tuning regula- } \\
\text { tory network which could play crucial roles in various physi- } \\
\text { ological processes through RNA silencing by base pairing } \\
\text { with complementary mRNA sequences (Bartel 2004). They } \\
\text { have generated considerable interest in the field of neuro- } \\
\text { biology especially in neural development, aging and neu- } \\
\text { rodegeneration (Kalani et al. 2014; Barmada 2015). These }\end{array}$}} \\
\hline $\mathrm{PB}$ & & Phosphate buffer & & \\
\hline $\mathrm{PB}$ & & Phosphate-buffered saline & & \\
\hline \multicolumn{3}{|c|}{$\begin{array}{l}凶 \text { Robert Gábriel } \\
\text { gabriel@ttk.pte.hu }\end{array}$} & & \\
\hline 1 & \multicolumn{2}{|c|}{$\begin{array}{l}\text { Department of Experimental Zoology and Neurobiology, } \\
\text { University of Pécs, Ifjúság útja } 6 \text {, Pécs } 7624 \text {, Hungary }\end{array}$} & $\begin{array}{l}\text { small mol } \\
\text { able to bin }\end{array}$ & $\begin{array}{l}\text { e only 20-25 nucleotides long, and are } \\
\text { ple targets (Barter et al. 2015). Although }\end{array}$ \\
\hline 2 & \multicolumn{2}{|c|}{$\begin{array}{l}\text { Department of Medical Biology, University of Pécs, Pécs, } \\
\text { Hungary }\end{array}$} & $\begin{array}{l}\text { individual } \\
\text { cases they }\end{array}$ & $\begin{array}{l}\text { A-s may have multiple targets, in several } \\
\text { ell-defined role in the case of an indi- }\end{array}$ \\
\hline & \multicolumn{2}{|c|}{$\begin{array}{l}\text { János Szentágothai Research Centre, University of Pécs, } \\
\text { Pécs, Hungary }\end{array}$} & $\begin{array}{l}\text { vidual cell } \\
\text { and somet }\end{array}$ & $\begin{array}{l}\text { target protein regulating expression level } \\
\text { cell fate (Bartel 2004). Organ-specific }\end{array}$ \\
\hline
\end{tabular}


microRNA maps have also been prepared (Karali et al. 2010; Diaz et al. 2015; Zhou et al. 2016) to monitor developmental or pathological processes at this regulatory level.

There are several opportunities to examine the expression of the microRNA-s. While qPCR, microRNA array or RNA-Seq analysis are common techniques for monitoring the quantity and even more the qualitative profile of microRNA-s in an appropriate timeframe, in situ hybridisation (ISH) is the only method that could provide evidence about localization of microRNAs within organisms, organs, tissues or cells (Obernosterer et al. 2007; Mohr and Mott 2015). However, the spatial resolution offered by conventional microRNA hybridisation is rather poor (Ryan et al. 2006; Karali et al. 2010). Since the emergence of $T_{\mathrm{m}}$-normalized, ultra-sensitive locked nucleic acid (LNA) probes much more information have become available on spatial distribution of microRNAs (Obernosterer et al. 2007; Thompson et al. 2007; Kasai et al. 2016). However, these seminal works have mainly focused on the detection of highly expressed brain microRNAs. At the same time revealing low-abundance of microRNA-s or microRNA-s from other than brain tissues could still prove challenging for researchers and always requires time-consuming optimisation steps in each laboratory. In our laboratory, we perform experiments on retinal development, aging and metabolic retinal degenerations (e.g. Szabadfi et al. 2014; Kovács-Valasek et al. 2017; Lakk et al. 2017). All these aspects may potentially involve microRNA regulation (Mortuza et al. 2014; Rasheed et al. 2014; SmitMcBride et al. 2014; Chung et al. 2015). Therefore, this paper aims to improve our ability to obtain widespread information on microRNA regulation under experimental conditions by enhancing fluorescent detection of microRNA-s. We also describe how in situ hybridisation can be combined with (single or double labelling) immunocytochemistry.

\section{Materials and supplies}

\section{Animals}

In the present study developing Wistar rats were used as a model system to analyse retinal microRNAs in the first 3 postnatal weeks (P7, $n=3 ; \mathrm{P} 10, n=5 ; \mathrm{P} 15, n=5 ; \mathrm{P} 21, n=3)$. All the animal care and handling procedures were performed according to the ethical guidelines, approved by University of Pécs Animal Ethics committee (BAI/35/51-58/2016). The rats were kept on $12 \mathrm{~h}$ light/dark cycle. Food and water were available ad libitum.

\section{Equipment and supplies}

The following equipment and supplies were used in the course of our study: CM1860 UV Cryostat (Leica, Wetzlar,
Germany); Super Frost Ultra Plus glass slides (Thermo Fisher Scientific, Budapest, Hungary); SI-1202 EnviroGenie Scientific Industries Inc. incubator (Scientific Industries, Bohemia, USA); glass beakers; Olympus IX 81 inverse platform-Olympus Fluoview FV-1000 Laser Confocal Scanning Microscope (Olympus, Tokyo, Japan); Adobe Photoshop 7.0 program for image processing.

\section{Buffers and solutions}

For RNA protection diethylpyrocarbonate (DEPC; SigmaAldrich, Budapest, Hungary) and RNase Away (Thermo Fisher Scientific) solutions were used. For preparing fixatives and buffer solutions sodium hydroxide (SigmaAldrich), paraformaldehyde (PFA; Merck, Budapest, Hungary), sucrose (Sigma-Aldrich), triethanolamine (TEA; Sigma-Aldrich), acetic anhydride (Sigma-Aldrich), sodium chloride (Sigma-Aldrich), ethylenediaminetetraacetic acid (EDTA; Sigma-Aldrich), disodium hydrogen phosphate dehydrate $\left(\mathrm{Na}_{2} \mathrm{HPO}_{4} \times 2 \mathrm{H}_{2} \mathrm{O}\right.$; VWR), sodium dihydrogen phosphate anhydrous $\left(\mathrm{NaH}_{2} \mathrm{PO}_{4}\right.$; Spektrum 3D, Pécs, Hungary) and trisodium citrate dihydrate (Reanal, Budapest, Hungary) were utilised. Denhardt's solution (Thermo Fisher Scientific) and concentrated hydrochloric acid $(\mathrm{HCl}$; Reanal) were also purchased for this purpose. Shandon ${ }^{\mathrm{TM}}$ Cryomatrix (Thermo Fisher Scientific) was the embedding material for sectioning while proteinase K (Thermo Fisher Scientific) pretreatment provided proper reagent penetration. For hybridisation formamide (Sigma-Aldrich), yeast RNA (Roche, Budapest, Hungary), and 5'-DIG-labeled LNA probe were used. Signal detection utilised anti-digoxigenin (mouse)-horseradish peroxidase (anti-DIG HRP) conjugate (Perkin Elmer, Per-Form Hungary Kft., Budapest, Hungary) and tyramide signal amplification (TSA) fluorescence kit (Perkin Elmer). All information on chemicals are collected in Table 1, and all the immune and hybridisation reagents in Table 2.

\section{Equipment and preparation of reagents}

RNase-free environment is essential. All equipment and working surfaces were treated with RNase Away (Thermo Fisher Scientific) or dry heat sterilization at $170{ }^{\circ} \mathrm{C}$ for at least $8 \mathrm{~h}$. Caps have been soaked in DEPC-treated water overnight at $37{ }^{\circ} \mathrm{C}$ and then autoclaved. Note that solutions containing Tris cannot be treated with DEPC. When DEPC-treated solution was needed we added $1 \mathrm{ml}$ of DEPC to the 11 of solution, swirled it on a magnetic stand at room temperature for $1 \mathrm{~h}$ in a fume hood and autoclaved at $121^{\circ} \mathrm{C}$ for $20 \mathrm{~min}$. When $0.2 \mathrm{M}$ phosphate buffer (PB) was needed we added $4.8 \mathrm{~g}$ of $\mathrm{NaH}_{2} \mathrm{PO}_{4}$ and $28.48 \mathrm{~g}$ of $\mathrm{Na}_{2} \mathrm{HPO}_{4} \times 2 \mathrm{H}_{2} \mathrm{O}$ to 11 of DEPC-treated water. We made phosphate-buffered saline (PBS) from fresh PB 
Table 1 Chemicals used during the protocols

\begin{tabular}{|c|c|c|c|c|}
\hline Chemicals & Company & Order numbers & Stock solution & Working solution \\
\hline Acetic-anhydride & Sigma-Aldrich, Budapest, Hungary & 320102 & $99 \%$ & $0.2 \%$ \\
\hline Diethylpyrocarbonate (DEPC) & Sigma-Aldrich, Budapest, Hungary & D5758 & $97 \%$ & $0.1 \%$ \\
\hline Formamide & Sigma-Aldrich, Budapest, Hungary & F9037 & $99.5 \%$ & $50 \%$ \\
\hline Hydrochloric acid $(\mathrm{HCl})$ & Reanal, Budapest, Hungary & $30715-0-0169$ & $37 \%$ & Used for $\mathrm{pH}$ adjustment \\
\hline Triethanolamine (TEA) & Sigma-Aldrich, Budapest, Hungary & 90279 & $99 \%$ & $10 \%$ \\
\hline Ethylenediaminetetraacetic acid (EDTA) & Sigma-Aldrich, Budapest, Hungary & E5134 & Pure & $0.5 \mathrm{M}$ \\
\hline $\begin{array}{l}\text { Di-sodium hydrogen phosphate dehy- } \\
\text { drate }\left(\mathrm{Na}_{2} \mathrm{HPO}_{4} \times 2 \mathrm{H}_{2} \mathrm{O}\right)\end{array}$ & VWR, Hungary & $10028-24-7$ & Pure & $7.1 \%$ \\
\hline Paraformaldehyde (PFA) & Merck, Budapest, Hungary & $30525-89-4$ & Pure & $4 \%$ \\
\hline $\begin{array}{l}\text { Sodium-dihydrogen phosphate anhy- } \\
\text { drous }\left(\mathrm{NaH}_{2} \mathrm{PO}_{4}\right)\end{array}$ & Spektrum 3D, Pécs, Hungary & 06090543 & Pure & $2.4 \%$ \\
\hline Blocking reagent & Roche, Budapest, Hungary & 11096176001 & Pure & $0.5 \%$ \\
\hline Sodium-chloride & Sigma-Aldrich, Budapest, Hungary & 71380 & Pure & $\begin{array}{l}\text { Used in different } \\
\text { concentration for dif- } \\
\text { ferent solutions }\end{array}$ \\
\hline Sucrose & Sigma-Aldrich, Budapest, Hungary & 84097 & Pure & $15 \%$ and $30 \%$ \\
\hline Trisodium-citrate dihydrate & Reanal, Budapest, Hungary & $34761-1-08-38$ & Pure & $0.3 \mathrm{M}$ \\
\hline Yeast RNA & Roche, Budapest, Hungary & 10109495001 & Pure & $0.5 \mathrm{mg} / \mathrm{ml}$ \\
\hline Sodium-hydroxide sol & Sigma-Aldrich, Budapest, Hungary & 72068 & $10 \mathrm{M}$ in $\mathrm{H}_{2} \mathrm{O}$ & used for $\mathrm{pH}$ adjustment \\
\hline Proteinase $\mathrm{K}$ & Thermo Fisher Scientific, Hungary & AM2546 & $20 \mathrm{mg} / \mathrm{ml}$ & $5 \mu \mathrm{g} / \mathrm{ml}$ \\
\hline Denhardt's solution & Thermo Fisher Scientific, Hungary & 750018 & $50 \times$ & $1 \times$ \\
\hline $\begin{array}{l}\text { Tyramide signal amplification (TSA) } \\
\text { fluorescence kit }\end{array}$ & $\begin{array}{l}\text { Perkin Elmer, Per-Form Hungary Kft., } \\
\text { Budapest, Hungary }\end{array}$ & NEL744001KT & Kit & $\begin{array}{l}\text { Dilution factor } \\
1: 50\end{array}$ \\
\hline $\begin{array}{l}\text { Anti-digoxigenin (mouse)-horse peroxi- } \\
\text { dase (anti-DIG HRP) conjugate }\end{array}$ & $\begin{array}{l}\text { Perkin Elmer, Per-Form Hungary Kft., } \\
\text { Budapest, Hungary }\end{array}$ & NEF832001EA & Kit & $\begin{array}{l}\text { Dilution factor } \\
1: 500\end{array}$ \\
\hline Calbindin D-28K & Swant, Switzerland & CB-38 & $200 \mu \mathrm{l}$ & Dilution factor 1:1000 \\
\hline Calretinin & Swant, Switzerland & CG1 & $200 \mu \mathrm{l}$ & Dilution factor 1:1000 \\
\hline Syntaxin & Santa Cruz Hungary & sc- 47,437 & $200 \mu \mathrm{l}$ & Dilution factor 1:100 \\
\hline
\end{tabular}

by adding $500 \mathrm{ml}$ of DEPC-treated $0.2 \mathrm{M} \mathrm{PB}$ to $500 \mathrm{ml}$ of ultrapure water, dissolved $9 \mathrm{~g}$ of $\mathrm{NaCl}$ in it and autoclaved at $121{ }^{\circ} \mathrm{C}$ for $20 \mathrm{~min}$. Fixative (4\% PFA, pH 7.4) was prepared freshly by adding $10 \mathrm{~g}$ of PFA powder to heated $100 \mathrm{ml}$ DEPC-treated PBS, kept at $68^{\circ} \mathrm{C}$ until PFA dissolved completely, adjusted $\mathrm{pH}$ to 7.4 with $1 \mathrm{~N} \mathrm{HCl}$ filled it up to $250 \mathrm{ml}$ and finally filtered it using a $45 \mu \mathrm{m}$ filter.

For proteinase $\mathrm{K}$ treatment, a specific buffer solution was prepared. Stock solutions were made of Tris- $\mathrm{HCl}$ (1 M, pH 7.5), NaCl (5 M) and EDTA (0.5 M) and autoclaved. To prepare proteinase $\mathrm{K}$ buffer, $5 \mathrm{ml} 1 \mathrm{M}$ Tris- $\mathrm{HCl}$ (pH 7.4), $2 \mathrm{ml} \mathrm{0.5} \mathrm{M} \mathrm{EDTA} \mathrm{and} 0.2 \mathrm{ml} 5 \mathrm{M} \mathrm{NaCl}$ were added to DEPC-treated water, the solution was filled up to $1000 \mathrm{ml}$ and autoclaved at $121{ }^{\circ} \mathrm{C}$ for $20 \mathrm{~min}$. To prepare proteinase $\mathrm{K}$ stock-solution $(20 \mathrm{mg} / \mathrm{ml})$, we dissolved $20 \mathrm{mg}$ proteinase $\mathrm{K}$ in $1 \mathrm{ml} 10 \mathrm{mM}$ Tris- $\mathrm{HCl}$ (pH 7.5) and stored at $-20{ }^{\circ} \mathrm{C}$ in aliquots until use. Proteinase $\mathrm{K}$ working solution $(5 \mathrm{mg} / \mathrm{ml})$ was prepared from $2.5 \mu$ proteinase $\mathrm{K}$ stock-solution for $10 \mathrm{ml}$ proteinase $\mathrm{K}$ buffer. The working solution was always freshly prepared.
For acetylation, a working solution was prepared $(250 \mu \mathrm{l}$ acetic anhydride was added to $100 \mathrm{ml} 0.1 \mathrm{M}$ triethanolamine (TEA; $\mathrm{pH}$ 8.0) in DEPC-treated water). We added $175.3 \mathrm{~g} 3 \mathrm{M} \mathrm{NaCl}$ and $88.2 \mathrm{~g} 0.3 \mathrm{M}$ trisodium citrate dihydrate to $20 \times$ saline-sodium citrate (SSC) $(\mathrm{pH}$ 7.0), adjusted the $\mathrm{pH}$ to 8.0 with $1 \mathrm{~N} \mathrm{HCl}$, filled it up to $1000 \mathrm{ml}$ and treated it with DEPC.

For hybridisation ( $50 \mathrm{ml}$ solution), we mixed $25 \mathrm{ml}$

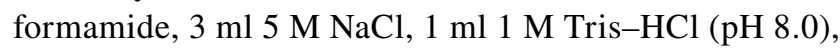
$0.5 \mathrm{ml} 0.5 \mathrm{M}$ EDTA, $1 \mathrm{ml}$ Denhardt's solution $(50 \times)$, $25 \mathrm{mg}$ yeast RNA and $18 \mathrm{ml}$ DEPC-treated water and stored it at $-20{ }^{\circ} \mathrm{C}$ in aliquots. For signal detection, TSA Plus Fluorescence method was used (TSA Plus Fluorescence Kit). To enhance labelling specificity, TNB blocking was performed (TN Blocking Buffer contains $10 \mathrm{ml} 1 \mathrm{M}$ Tris- $\mathrm{HCl}$ (pH 7.4) and $3 \mathrm{ml} 5 \mathrm{M} \mathrm{NaCl}$ in $100 \mathrm{ml}$ ultrapure water). For preparing the blocking solution, $500 \mathrm{mg}$ of blocking reagent was slowly dissolved in $100 \mathrm{ml}$ heated (RNA $T_{\mathrm{m}}-30{ }^{\circ} \mathrm{C}$ ) TN Blocking Buffer. After blocking, washing was followed with TNT Wash Buffer (50 ml $1 \mathrm{M}$ 


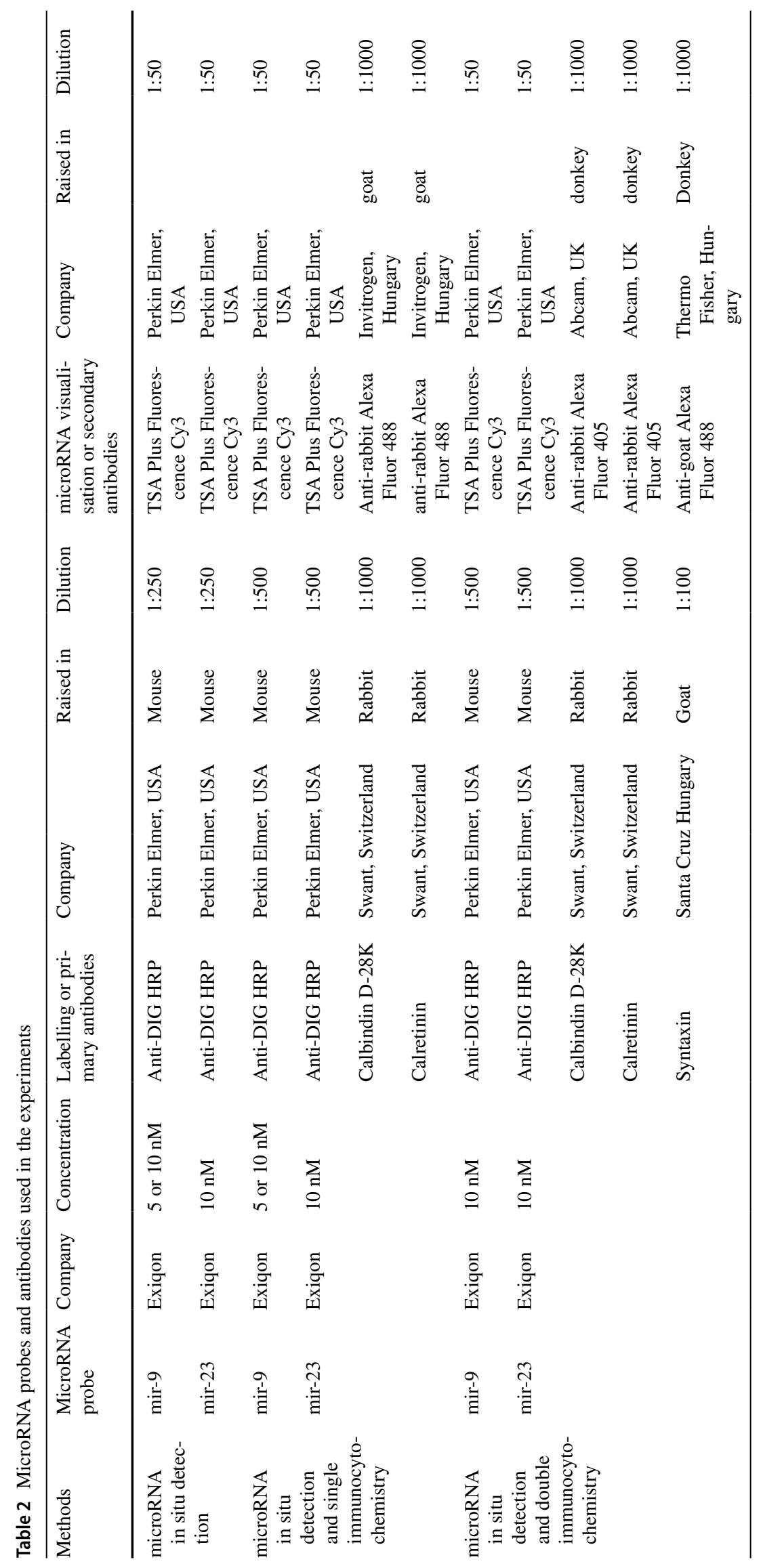


Tris- $\mathrm{HCl}(\mathrm{pH} 7.5), 15 \mathrm{ml} 5 \mathrm{M} \mathrm{NaCl}$ and $250 \mu \mathrm{l}$ Tween-20 to $500 \mathrm{ml}$ of ultrapure water).

\section{Workflow and detailed methods}

An approximate timeline and step-by-step instructions are presented in Fig. 1. All reagents and labware must be RNasefree and a particular care of preparing DEPC-treated solutions in heated sterilized glassware must be taken.

\section{Tissue preparation and sectioning}

Animals were killed with an overdose of isoflurane anaesthetics. The dissected eyecups were immediately fixed in $4 \%$ PFA in PBS for 20 min. For cryoprotection, the tissues were placed into $15 \%$ sucrose in PBS at room temperature until the tissue sank, and then into $30 \%$ sucrose in PBS at $4{ }^{\circ} \mathrm{C}$ overnight. Next day, the cryostat was cleaned with RNase Away and sterilized with the UV-C program before usage. Then the tissues were embedded in Shandon Cryomatrix for cutting $12 \mu \mathrm{m}$ sections and transferred to Super Frost Ultra Plus slides. Only this type of slide could be used successfully without the risk of section loss. Slides were dried for $30 \mathrm{~min}$ in a biological safety cabinet and were stored at $-80{ }^{\circ} \mathrm{C}$ until use.

\section{Pre-treatment}

On the experiment day, slides were warmed to room temperature. Dried sections were fixed in 4\% PFA for $10 \mathrm{~min}$ at room temperature and then washed three times with PBS for $5 \mathrm{~min}$. To increase the permeability and the hybridisation efficiency, the proteinase $\mathrm{K}$ working solution was freshly prepared, the slides were treated with $5 \mu \mathrm{g} / \mathrm{ml}$ proteinase $\mathrm{K}$ for $10 \mathrm{~min}$ at room temperature, and finally washed three times with PBS for 5 min. During washing, the acetylation working solution could be prepared by adding $250 \mu$ acetic anhydride with constant stirring to $100 \mathrm{ml} 0.1 \mathrm{M}$ TEA. This solution was then spread on the sections for $10 \mathrm{~min}$ to reduce background. This step ensured decreased binding of the negatively charged RNA probe to the acetylated negatively charged amino groups in the proteins. After the acetylation step, slides were rinsed three times with PBS for 5 min and then pre-hybridised with $700 \mu$ hybridisation solution at room temperature for $4 \mathrm{~h}$. The in situ hybridisation chamber containing a vial of $50 \%$ formamide with $1 \times \mathrm{SSC}$ was prepared by pre-warming to the hybridisation temperature. The hybridisation temperature was calculated from the melting temperature $\left(T_{\mathrm{m}}\right)$ of the LNA-RNA probe according to manufacturer's recommendation and set it $30{ }^{\circ} \mathrm{C}$ below the RNA $T_{\mathrm{m}}$. For instance, in our case, the RNA $\mathrm{T}_{\mathrm{m}}$ of mir-9 probe was $81{ }^{\circ} \mathrm{C}$ so the hybridisation temperature was set at $51{ }^{\circ} \mathrm{C}$, while for mir- 23 probe at $53{ }^{\circ} \mathrm{C}$.

\section{Hybridisation}

The hybridisation mixture was prepared by adding $10 \mathrm{nM}$ 5'-DIG labelled LNA-probe to hybridisation solution (the amount of the probe should be optimised). The probe was heated to $65{ }^{\circ} \mathrm{C}$ for $5 \mathrm{~min}$ to denature then immediately placed on ice. The pre-hybridisation buffer was replaced with the hybridisation buffer containing the appropriated amount of probe $(250 \mu \mathrm{l}$ per slide). The slides were incubated in the humidified chamber overnight at the temperatures calculated from the $T_{\mathrm{m}}$-values as indicated.

\section{Stringency washes}

First, $5 \times \mathrm{SSC}, 0.2 \times \mathrm{SSC}$ solutions and $1 \times \mathrm{SSC}$ solution containing $50 \%$ formamide and $0.1 \%$ Tween- 20 were prepared, pre-warmed above the temperature of the hybridisation solution. Slides were then washed at $5-10{ }^{\circ} \mathrm{C}$ above the hybridisation temperature once with $5 \times \mathrm{SSC}$ for $15 \mathrm{~min}$, twice with $1 \times$ SSC containing $50 \%$ formamide and $0.1 \%$ Tween- 20 for $30 \mathrm{~min}$ and finally once with $0.2 \times \mathrm{SSC}$ for $15 \mathrm{~min}$. All these steps were performed at $65^{\circ} \mathrm{C}$. Slides were then rinsed with PBS for $15 \mathrm{~min}$ at room temperature.

\section{Simultaneous antibody application for microRNA detection and immunocytochemistry}

TNB Blocking solution was warmed to room temperature. Slides were incubated in TNB Blocking solutions for $30 \mathrm{~min}$. The anti-DIG HRP conjugated antibody was diluted (1:250) in TNB Blocking solutions. The diluted anti-DIG HRP was administered to each slide, which were incubated for 30 min and then washed in TNT buffer three times for 5 min. When in situ hybridisation and immunostaining was performed simultaneously, the primary antibody solution was prepared in an appropriate concentration, applied together with anti-DIG HRP (1:500 dilution) and then slides were incubated overnight. Slides were rinsed in TNT buffer six times for $5 \mathrm{~min}$. Species-specific secondary antibody solution (dilution 1:1000-1:10,000 depending on the make of the antibody) was prepared and slides were incubated for $2 \mathrm{~h}$ to visualise immunostaining, then slides were washed in TNT buffer three times for $5 \mathrm{~min}$. At this point, the tyramide signal amplification (TSA) reaction was applied to reveal microRNA-s with high sensitivity. First, TSA Plus Working Solution was prepared by diluting TSA Plus Cyanine-tyramide Stock solution 1:50 in amplification buffer. Then $150 \mu \mathrm{l}$ TSA Plus Working Solution added the slides to incubate them at room temperature for $10 \mathrm{~min}$ followed by washing in TNT buffer three times for 5 min. Prolong Gold 
Fig. 1 Flowchart of the protocol. The flowchart gives a brief overview of the in situ microRNA hybridisation procedure (left side), in addition to the main point of simultaneous detection of microRNA and cellular protein markers by combining microRNA in situ hybridisation with (single and double) immunocytochemistry (right side). Dashed line shows the border of the tissue preparation and labelling procedure, when a stopping point could be held and slides could be stored at $-80{ }^{\circ} \mathrm{C}$ until use

containing mounting medium (with or without DAPI) was added to each slide and coverslipped. Slides were imaged the following day by a confocal microscope $(40 \times / 0.75 \mathrm{Ph} 2$ UPlanFLN lens, Olympus) with the adequate laser beams.

\section{Results}

The in situ microRNA hybridisation protocol was optimized for retinal sections from the postnatal day (PD) 7, 10, 15 and 21 , which days are known to correspond with the end of cell generation, beginning of synaptogenesis, start of functional vision and completion of retinal development, respectively (Bagnoli et al. 2003; Centanin and Wittbrodt 2014). The purpose of detecting mir-9, which is known as a key regulator of the early to late developmental transition in retinal progenitors was to illustrate the appearance of a highly expressed microRNA. Incubation conditions profoundly influence labelling intensity and electivity (Fig. 2a-d), particularly the temperature of stringency washes (Fig. 2b; washing happened at the same temperature as incubation with the probe) and probe concentration (Fig. $2 \mathrm{c}, \mathrm{d}-10 \mathrm{nM}$ probe concentration; images from the $5 \mathrm{nM}$ probe concentration experiments and low-temperature stringency washes are not shown because of the resulting low intensity or high background labelling). The mir-9 signal was detectable at hybridization temperatures of both $30^{\circ} \mathrm{C}$ and $41{ }^{\circ} \mathrm{C}$ below its RNA $T_{\mathrm{m}}\left(81^{\circ} \mathrm{C}\right)$ in the postnatal rat retina. Optimal labelling could be achieved using $10 \mathrm{nM}$ probe concentration incubated at $\sim 30^{\circ} \mathrm{C}$ below RNA probe $T_{\mathrm{m}}$-value $\left(51^{\circ} \mathrm{C}\right)$ and stringency washes performed at $65^{\circ} \mathrm{C}$ (Fig. 2d). This signal was characteristically present in the ganglion cell layer (GCL), with only a few cells showing labelling in the inner nuclear layer (INL; Fig. 2d). Further experiments have been performed using different $\mathrm{H}_{2} \mathrm{O}_{2}$ concentrations and proteinase $\mathrm{K}$ treatment schedules which also had some but not profound influence on labelling intensity (Table 3 ). Note that proteinase $\mathrm{K}$ treatment was necessary to achieve proper labelling ( $1 \mu \mathrm{g} / \mathrm{ml}$ was not enough, even with 20 min treatment time, to get satisfactory signal), however, overtreatment ( $10 \mu \mathrm{g} / \mathrm{ml}$ for $1 \mathrm{~min}$ ) often resulted in tissue damage and section loss (Table 3 ). The optimum treatment was $5 \mu \mathrm{g} / \mathrm{ml}$ for $10 \mathrm{~min}$.

The microRNA mir-23 is a potential regulator in the development of the GABAergic system that is particularly elaborate in the retina (Yang 2004). In our mir-23

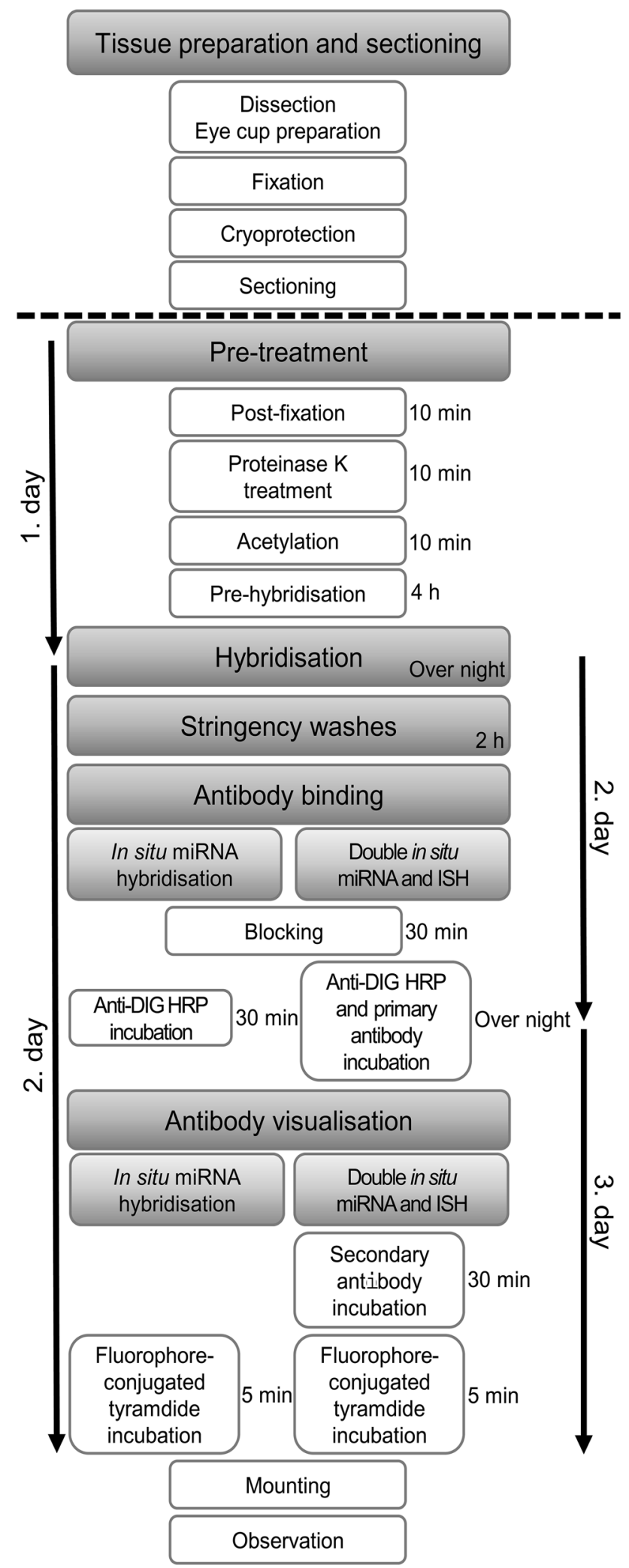

experiments (Fig. 3) expression was observed best at $53{ }^{\circ} \mathrm{C}$ hybridisation temperature. Signal could not be observed in sections incubated without microRNA probe and 
anti-DIG-HRP or slides incubated with anti-DIG HRP only (Fig. 3a2, b, respectively), both tests served as negative controls. Just like in the case of mir-9, mir-23 label was detected most prominently in the GCL (Fig. 3c, d). Hybridisation temperature had a profound effect on labelling intensity; at $40{ }^{\circ} \mathrm{C}$ staining was less intense (Fig. $3 \mathrm{c}$ ) while $53{ }^{\circ} \mathrm{C}$ (calculated from $T_{\mathrm{m}}$ ) yielded the best results (Fig. 3d). Besides cells in the GCL (Fig. 3e1, e2), staining was observed for perhaps all horizontal (Fig. 3f1, f2) and some amacrine cells (Fig. 3 e1, f). The inner limiting membrane and some capillaries occasionally showed non-specific staining (Fig. 3e2). To optimise the probe concentration, values ranging from 1 to $20(1,2,5,10,20) \mathrm{nM}$ were tested and specific signal was obtained with various intensities and backgrounds (images not shown). The optimal probe concentration was $10 \mathrm{nM}$ for this microRNA, similarly to mir-9.

For further improvement of the methodology, microRNA in situ hybridisation was combined with immunocytochemistry (Fig. 4). The immunocytochemical procedure was integrated into the microRNA in situ hybridisation protocol, thus making possible to perform the multiple labelling protocol in 3 days. After the probe hybridisation and stringency wash steps, a common blocking step was performed for probe detection and immunocytochemistry, then anti-DIG HRP was applied simultaneously with the primary antibody of the immunocytochemical procedure. Combination of the two methodologies after our mild proteinase $\mathrm{K}$ treatment protocol became possible, and was useful for identifying cells expressing a particular microRNA and a calcium-binding protein (Fig. 4a, b-calbindin and calretinin, respectively). Stronger proteinase $\mathrm{K}$ treatment (longer incubation times, higher concentrations and/or higher temperature) resulted in the loss of antigenicity of the targeted protein markers thus making the simultaneous detection impossible (images not shown). To take this methodological improvement further we lastly decided to apply our protocol for simultaneous detection of mir-9, calbindin (a horizontal cell-specific marker in the retina) and syntaxin-3, a synaptic protein marker (Fig. 4c). We were successful in detecting these three markers in the horizontal cells (Fig. 4d). The distribution of the reaction product within the same cell is slightly different (Fig. 4d1-d3), clearly indicating that the labels are specific and we found no evidence of any false positivity in our triple labelling protocol.

\section{Discussion}

In the present study, we described a detailed method for sensitive histological detection of microRNAs with simultaneous single or double immunocytochemical labelling. Several papers have reported microRNA in situ hybridisation detection (de Planell-Saguer et al. 2010; Kasai et al. 2016), either in frozen tissues (Obernosterer et al. 2007; Silahtaroglu et al. 2007) and/or in retina sections (Thompson et al. 2007; Singh et al. 2014). Double labelling protocols mostly focused on microRNA-mRNA co-detection (Kasai et al. 2016) and only very few papers have intended to combine microRNA in situ hybridisation with immunolabelling (Singh et al. 2014). The main advantages of our method can be summarised as follows: (1) our proteinase $\mathrm{K}$ treatment protocol makes possible a better probe penetration then in the previous papers but at the same time it does not destroy protein antigens allowing for the simultaneous immunocytochemical detection of cellular proteins; (2) hybridisation and stringency washes at different temperatures, calculated from the $T_{\mathrm{m}}$ of the actual probe, result in stronger and more elective labelling, and (3) a better cellular resolution of the microRNA labelled cells. To our knowledge, this study is the first that aimed at to localise a microRNA expression with two protein markers at the same time in frozen retinal sections. Thus, this technique could be suitable for simultaneous detection of a particular microRNA and a potentially associated target protein in a cell that is also identified by its characteristic cellular marker protein. In view of these results through this protocol, we expect to get a deeper insight into retinal
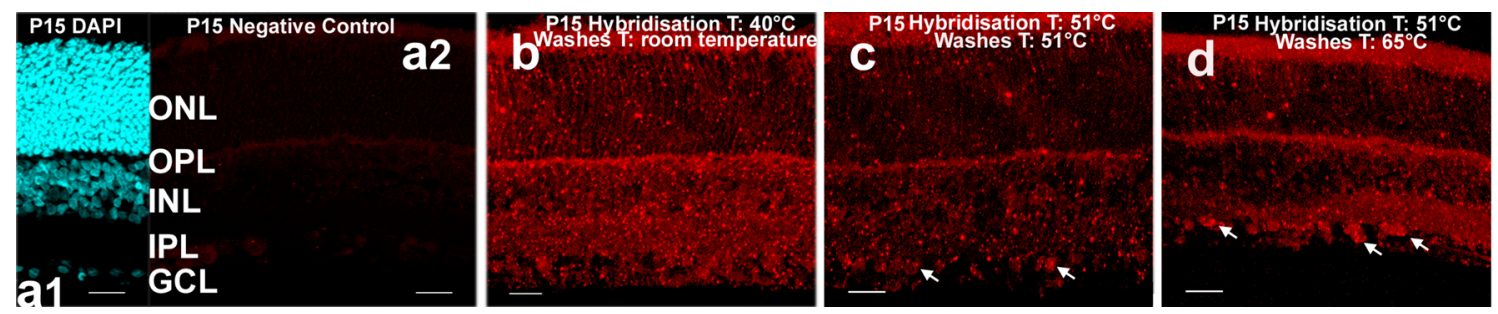

Fig. 2 Demonstration of microRNAs (mir-9, red) in situ detection in rat retina tissues. Scale bars: $25 \mu \mathrm{m}$ in all images (a1, a2, b-d). Relevant information regarding age and treatment conditions is shown on the images. $G C L$ ganglion cell layer, $I P L$ inner plexiform layer, $I N L$ inner nuclear layer, $O P L$ outer plexiform layer, $O N L$ outer nuclear layer. A false-colored (cyan) 4',6-diamidine-2-phenylindole-dihydro- chloride (DAPI) nuclear staining demonstrate the nuclear layers (a1), while slides incubated without microRNA probe served as negative controls (a2). Hybridisation was performed at $40{ }^{\circ} \mathrm{C}(\mathbf{b})$ and $51{ }^{\circ} \mathrm{C}$ $(\mathbf{c}, \mathbf{d})$, while stringency washes varied between room temperature $(\mathbf{b})$, $51{ }^{\circ} \mathrm{C}(\mathbf{c})$ and $65{ }^{\circ} \mathrm{C}(\mathbf{d})$. The probe concentration was $10 \mathrm{nM}(\mathbf{b}-\mathbf{d})$. Note the elective labelling of the cells in the GCL (arrows in $\mathbf{c}$ and $\mathbf{d}$ ) 
physiological processes such as cellular proliferation, differentiation or apoptosis.

For sensitive and highly specific microRNA in situ hybridisation, several challenges had to be overcome (Urbanek et al. 2015). The first crucial steps are tissue preparation and pretreatment, which influenced the detectability remarkably in

Table 3 Outcomes of the proteinase $\mathrm{K}$ digestion and hydrogen peroxide $\left(\mathrm{H}_{2} \mathrm{O}_{2}\right)$ treatment during microRNA in situ hybridisation at room temperature

\begin{tabular}{lccll}
\hline Treatment & \multicolumn{4}{l}{ Incubation time } \\
\cline { 2 - 5 } & $1 \mathrm{~min}$ & $5 \mathrm{~min}$ & $10 \mathrm{~min}$ & $20 \mathrm{~min}$ \\
\hline Proteinase & K concentration & & & \\
$1 \mu \mathrm{g} / \mathrm{ml}$ & + & + & + & - \\
$5 \mu \mathrm{g} / \mathrm{ml}$ & + & ++ & +++ & - \\
$10 \mu \mathrm{g} / \mathrm{ml}$ & + & + & - & - \\
$\mathrm{H}_{2} \mathrm{O}_{2}$ concentration & & & & \\
$0.3 \%$ & & & - & \\
$1 \%$ & & & - & \\
$3 \%$ & & & - & \\
\hline
\end{tabular}

The '-' sign shows negative effect of the procedure, mainly tissue damage or section loss. While ' + ' symbols represents prosperous outcomes. The number of + signs correlates with favourable changes, such as better signal-to-noise ratio or more specific signal detection the case of these small RNA molecules. For frozen retinal sections, generally a rapid (30 min-2 h) 4\% paraformaldehyde fixation has been used. In contrast to this, various descriptions can be found for pre-treatments that differ significantly in the order of the steps, the treatment/incubation time or applied concentration of chemicals. These steps serve to enhance probe penetration and target sequence matching. To improve permeabilisation or to remove protein that surrounds the target sequence some protocols prescribe proteinase $\mathrm{K}$ treatment (Obernosterer et al. 2007; Silahtaroglu et al. 2007; Thompson et al. 2007), whereas others do not (Song et al. 2010; de Planell-Saguer et al. 2010; Nielsen et al. 2014). Our experiments confirm that proteinase $\mathrm{K}$ treatment is essential for elective microRNA detection, but it demands special caution since overtreatment may cause tissue damage and section loss. Therefore, optimal concentration and incubation time of proteinase $\mathrm{K}$ treatment should be determined for each tissue type. Another key step is acetylation to decrease background, however, most protocols do not vary significantly in this respect including our currently suggested method. On the other hand, the tyramide signal amplification method that uses horseradish peroxidase to visualize microRNA labelling is a sensitive step. Using peroxidase enzyme makes it essential to eliminate the endogenous tissue peroxidase activity which could result in a very high background. For this reason, $\mathrm{H}_{2} \mathrm{O}_{2}$
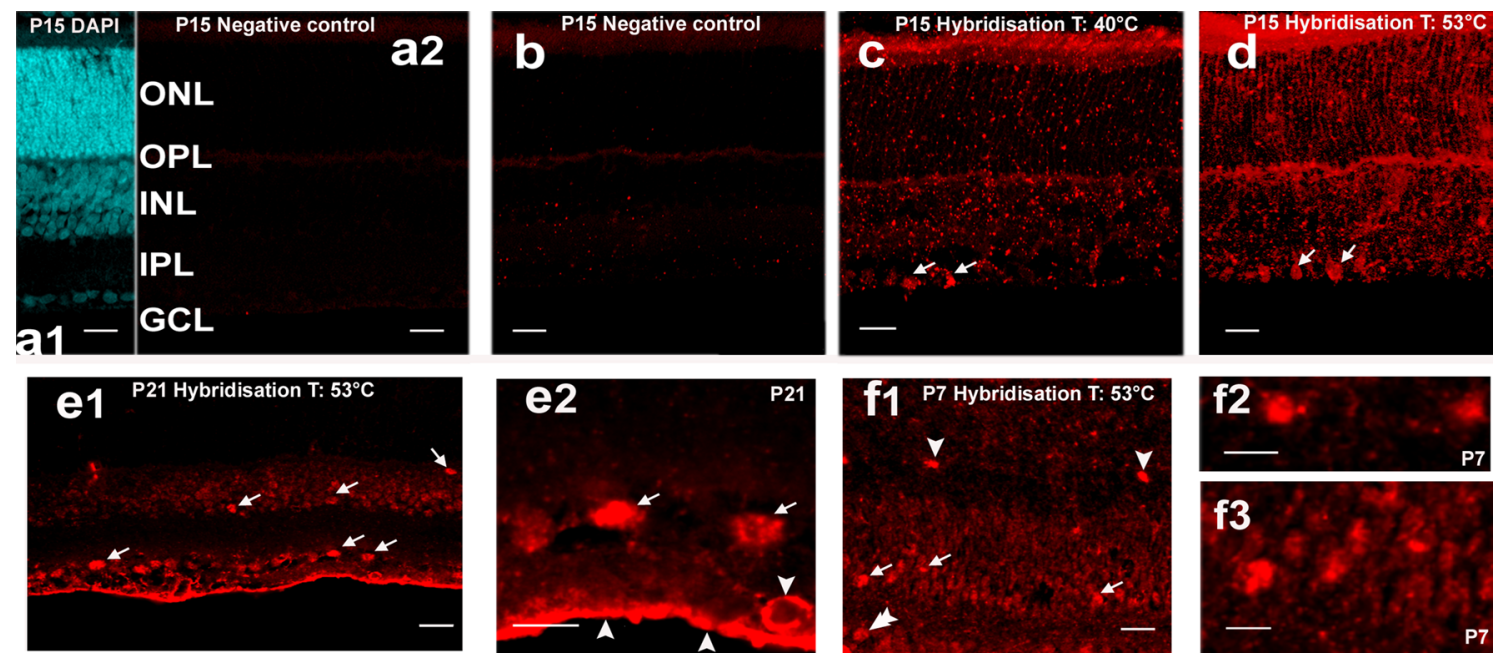

Fig. 3 In situ detection of mir-23 in rat retina sections. GCL ganglion cell layer, $I P L$ inner plexiform layer, $I N L$ inner nuclear layer, $O P L$ outer plexiform layer, $O N L$ outer nuclear layer, $I L M$ inner limiting membrane. Relevant information regarding age and treatment conditions is shown on the images. Scale bars: $20 \mu \mathrm{m}(\mathbf{a} 1, \mathbf{a 2}, \mathbf{b}-\mathbf{d}, \mathbf{e 1}$, f1) and $10 \mu \mathrm{m}(\mathbf{e} 2, \mathbf{f} 2, \mathbf{f 3})$. For indication, the position of the nuclear layers DAPI counterstaining was applied (a1). The negative controls $(\mathbf{a} 2, \mathbf{b})$ were obtained with sections incubated in the absence of both the mir-23 probe and the anti-DIG-horseradish peroxidase (HRP)labelled antibody (a2); to detect the specificity of tyramide signal amplification sections were incubated without probe but with antiDIG HRP antibody and tyramide signal amplification system (b).
Representative images of mir-23 hybridised at $40{ }^{\circ} \mathrm{C}(\mathbf{c})$ and $53{ }^{\circ} \mathrm{C}$ (d); arrows indicate labelled cells. Note the more prominent staining in d. Strong mir-23 labelling can be seen in the cells of INL and GCL at $\mathrm{P} 21$ at $53{ }^{\circ} \mathrm{C}$ hybridisation temperature (e1-arrows). Presumed ganglion cells are especially strongly stained (e2 - arrows). Non-specific staining of the inner limiting membrane and a capillary is indicated with arrowheads. As early as $\mathrm{P} 7$, the mir-23 signal can already be detected in several retinal cell types (f1) including horizontal cells (arrowheads), amacrine cells (arrows) and a presumed ganglion cell (double arrowhead). Enlarged image of horizontal (f2) and amacrine (f3) cells, respectively 

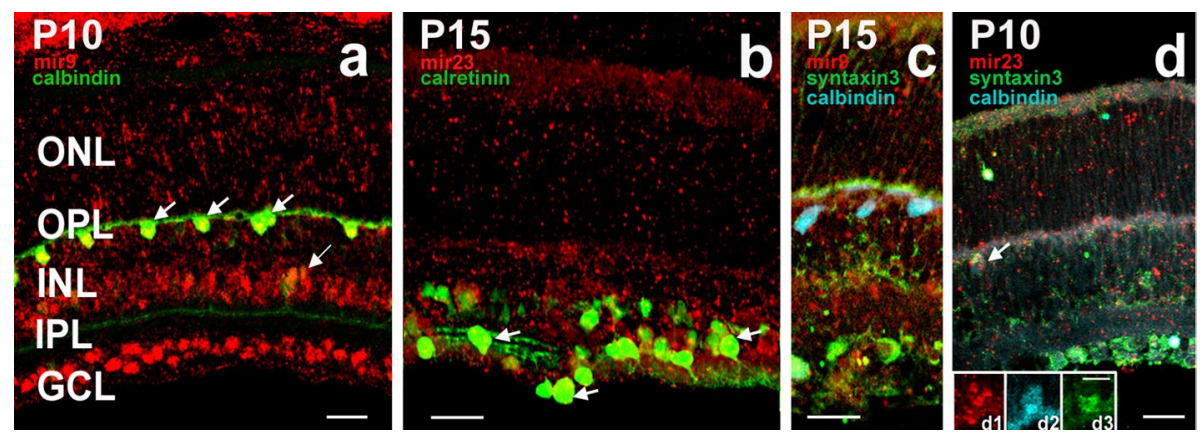

Fig. 4 Co-detection of microRNAs (mir-9, mir-23), neuron-specific marker protein (calbindin D28k or calretinin) and synaptic marker protein (syntaxin-3), respectively. GCL ganglion cell layer, IPL inner plexiform layer, $I N L$ inner nuclear layer, $O P L$ outer plexiform layer, $O N L$ outer nuclear layer. Relevant information regarding age and treatment conditions is shown on the images. Scale bars: $25 \mu \mathrm{m}$ (a-d) and $5 \mu \mathrm{m}(\mathbf{d 1}-\mathbf{d} 3$ ). In situ hybridization detection of mir-9 (redCy3) showed specific co-labelling in all horizontal cells (greenAlexa Fluor 488; calbindin D28k, marked with arrows), while only a few amacrine cells (one indicated with arrow) were double labelled for mir-9 and calbindin. Cells in the GCL were labelled invariably for mir-9 only (a). Dual ISH-IHC of mir-23 (red-Cy3) and calretinin (green-Alexa Fluor 488) was detected mainly in the amacrine cells

treatment is generally used as a pre-treatment step. We found that this procedure could cause serious tissue degradation in certain conditions, so we minimised this step in our protocol. The most critical steps, however, are the hybridization temperature and the stringency washes. They both have crucial effects on the intensity and specificity of in situ hybridisation signals. Karali and co-workers in their comprehensive study reported a detailed description about the applied hybridisation temperatures for the different probes (Karali et al. 2010). As mentioned in their work $40{ }^{\circ} \mathrm{C}$ was applied for mir-9 and mir-23 hybridisation, but our study demonstrates that this condition could give a high background staining. In contrast, the manufacturer recommends using the miRCURY LNA probes at $30{ }^{\circ} \mathrm{C}$ below the microRNA $T_{\mathrm{m}}$, so we calculated the hybridisation temperature from the probe sequence. Our examination confirmed that the hybridisation at $51{ }^{\circ} \mathrm{C}$ and $53{ }^{\circ} \mathrm{C}$ was most effective for specific detection of mir-9 and mir-23, respectively. However, the signal-to-noise ratio even then could be non-satisfactory, so optimisation of another important parameter, the temperature of stringency washes was necessary to avoid false-positive signals. When the wash steps following the hybridisation procedure were carried out less than or equal to hybridisation temperature it caused very strong false-positive and/or background signals. In contrast, hybridisation at a higher temperature could even destroy the specific probe-target hybridisation and even eliminate the signal. The best signal-to-noise ratio could be achieved when hybridisation was performed at $30{ }^{\circ} \mathrm{C}$ below the microRNA $T_{\mathrm{m}}$ (as probe manufacturer's offers) followed by stringency washes at $5-10{ }^{\circ} \mathrm{C}$ higher temperature. and presumed ganglion cell bodies in the GCL (b). A few doublelabelled cells are marked with arrows. A representative image showing the in situ hybridisation signal (red: mir9-Cy3) combined with double immunocytochemical labelling (blue: calbindin-Alexa Fluor405 and green: syntaxin-3 - Alexa Fluor 488) (c). Demonstration of triple labelling in P10 retinae. The in situ hybridisation signal (red: mir23-Cy3) combined with double immunocytochemical labelling (blue: calbindin-Alexa Fluor 405 and green: syntaxin-3Alexa Fluor 488). A triple-labelled horizontal cells is marked with arrow (d). Insert images demonstrate the overlap of ISH-dual IHC staining in a horizontal cell. The red signal (Cy3) is for mir-23 (d1), blue signal (Alexa Fluor 405) is for calbindin (d2) and green signal (AlexaFluor 488) is for syntaxin-3 (d3), respectively

In conclusion, this paper presents a refined method for visualizing microRNA expression. Successful combination of this method with immunocytochemical detection of proteins provides possibilities to get a deeper insight into the gene regulation networks during retinal histogenesis. Since in situ hybridisation serves information on spatial distribution of the microRNAs, this technique cannot be used for quantitative determination. Our ongoing investigations focus on the expression profile of retinal microRNAs in development and quantify the most important players by next-generation sequencing and quantitative PCR measurements.

Acknowledgements We would like to extend our deep thank to Alina Bolboaca for her technical assistance.

Funding This work was supported by Hungarian Brain Research Program 2017-1.2.1-NKP-2017-00002 and NKFIH-119289 to Robert Gabriel.

\section{Compliance with ethical standards}

Conflict of interest The authors have declared that no conflict of interest exists.

Open Access This article is distributed under the terms of the Creative Commons Attribution 4.0 International License (http://creativeco mmons.org/licenses/by/4.0/), which permits unrestricted use, distribution, and reproduction in any medium, provided you give appropriate credit to the original author(s) and the source, provide a link to the Creative Commons license, and indicate if changes were made. 


\section{References}

Bagnoli P, Dal Monte M, Casini G (2003) Expression of neuropeptides and their receptors in the developing retina of mammals. Histol Histopathol 18:1219-1242. https://doi.org/10.14670/HH-18.1219

Barmada SJ (2015) Linking RNA dysfunction and neurodegeneration in amyotrophic lateral sclerosis. Neurotherapeutics 12:340-351. https://doi.org/10.1007/s13311-015-0340-3

Bartel DP (2004) MicroRNAs. Cell 116:281-297. https://doi. org/10.1016/S0092-8674(04)00045-5

Barter MJ, Tselepi M, Gõmez R et al (2015) Genome-wide microRNA and gene analysis of mesenchymal stem cell chondrogenesis identifies an essential role and multiple targets for miR-140-5p. Stem Cells 33:3266-3280. https://doi.org/10.1002/stem.2093

Centanin L, Wittbrodt J (2014) Retinal neurogenesis. Development 141:241-244. https://doi.org/10.1242/dev.083642

Chung SH, Gillies M, Sugiyama Y et al (2015) Profiling of microRNAs involved in retinal degeneration caused by selective Müller cell ablation. PLoS One 10:e0118949. https://doi.org/10.1371/journ al.pone.0118949

de Planell-Saguer M, Rodicio MC, Mourelatos Z (2010) Rapid in situ codetection of noncoding RNAs and proteins in cells and formalin-fixed paraffin-embedded tissue sections without protease treatment. Nat Protoc 5:1061-1073. https://doi.org/10.1038/nprot .2010 .62

Diaz G, Zamboni F, Tice A, Farci P (2015) Integrated ordination of miRNA and mRNA expression profiles. BMC Genom. https://doi. org/10.1186/s12864-015-1971-9

Kalani A, Tyagi A, Tyagi N (2014) Exosomes: mediators of neurodegeneration, neuroprotection and therapeutics. Mol Neurobiol 49:590-600. https://doi.org/10.1007/s12035-013-8544-1

Karali M, Peluso I, Gennarino VA et al (2010) miRNeye: a microRNA expression atlas of the mouse eye. BMC Genom 11:715. https:// doi.org/10.1186/1471-2164-11-715

Kasai A, Kakihara S, Miura H et al (2016) Double in situ hybridization for microRNAs and mRNAs in brain tissues. Front Mol Neurosci 9:126. https://doi.org/10.3389/fnmol.2016.00126

Kovács-Valasek A, Szabadfi K, Dénes V et al (2017) Accelerated retinal aging in PACAP knock-out mice. Neuroscience 348:1-10. https://doi.org/10.1016/j.neuroscience.2017.02.003

Lakk M, Denes V, Kovacs K et al (2017) Pituitary adenylate cyclaseactivating peptide (PACAP), a novel secretagogue, regulates secreted morphogens in newborn rat retina. Investig Ophthalmol Vis Sci 58:565-572. https://doi.org/10.1167/iovs.16-20566

Mohr AM, Mott JL (2015) Overview of microRNA biology. Semin Liver Dis 35:3-11. https://doi.org/10.1055/s-0034-1397344

Mortuza R, Feng B, Chakrabarti S (2014) MiR-195 regulates SIRT1mediated changes in diabetic retinopathy. Diabetologia 57:10371046. https://doi.org/10.1007/s00125-014-3197-9
Nielsen BS, Møller T, Holmstrøm K (2014) Chromogen detection of microRNA in frozen clinical tissue samples using LNATM probe technology. Methods Mol Biol 1211:77-84. https://doi. org/10.1007/978-1-4939-1459-3_7

Obernosterer G, Martinez J, Alenius M (2007) Locked nucleic acidbased in situ detection of microRNAs in mouse tissue sections. Nat Protoc 2:1508-1514. https://doi.org/10.1038/nprot.2007.153

Rasheed VA, Sreekanth S, Dhanesh SB et al (2014) Developmental wave of Brn3b expression leading to RGC fate specification is synergistically maintained by miR-23a and miR-374. Dev Neurobiol 74:1155-1171. https://doi.org/10.1002/dneu.22191

Ryan DG, Oliveira-Fernandes M, Lavker RM (2006) MicroRNAs of the mammalian eye display distinct and overlapping tissue specificity. Mol Vis 12:1175-1184

Silahtaroglu AN, Nolting D, Dyrskjøt L et al (2007) Detection of microRNAs in frozen tissue sections by fluorescence in situ hybridization using locked nucleic acid probes and tyramide signal amplification. Nat Protoc 2:2520-2528. https://doi. org/10.1038/nprot.2007.313

Singh U, Keirstead N, Wolujczyk A et al (2014) General principles and methods for routine automated microRNA in situ hybridization and double labeling with immunohistochemistry. Biotech Histochem 89:259-266. https://doi.org/10.3109/10520295.2013.83982 5

Smit-McBride Z, Forward KI, Nguyen AT et al (2014) Age-dependent increase in miRNA-34a expression in the posterior pole of the mouse eye. Mol Vis 20:1569-1578

Song R, Ro S, Yan W (2010) In situ hybridization detection of microRNAs. Methods Mol Biol 629:287-294. https://doi. org/10.1007/978-1-60761-657-3_18

Szabadfi K, Szabo A, Kiss P et al (2014) PACAP promotes neuron survival in early experimental diabetic retinopathy. Neurochem Int 64:84-91. https://doi.org/10.1016/j.neuint.2013.11.005

Thompson RC, Deo M, Turner DL (2007) Analysis of microRNA expression by in situ hybridization with RNA oligonucleotide probes. Methods 43:153-161. https://doi.org/10.1016/j.ymeth .2007 .04 .008

Urbanek MO, Nawrocka AU, Krzyzosiak WJ (2015) Small RNA detection by in situ hybridization methods. Int J Mol Sci 16:1325913286. https://doi.org/10.3390/ijms 160613259

Yang X-L (2004) Characterization of receptors for glutamate and GABA in retinal neurons. Prog Neurobiol 73(2):127-150. https ://doi.org/10.1016/j.pneurobio.2004.04.002

Zhou M, Hara H, Dai Y et al (2016) Circulating organ-specific microRNAs serve as biomarkers in organ-specific diseases: implications for organ allo- and xeno-transplantation. Int J Mol Sci 17:8. https ://doi.org/10.3390/ijms17081232 